UDC 662.8

A. Khlopytskyi ${ }^{a}$, A. Savenkov ${ }^{b}$, O. Bliznjuk ${ }^{b}$, M. Skiba ${ }^{a}$, V. Vorobiova ${ }^{c}$, N. Masalitina ${ }^{b}$

\title{
LEACHING OF FeO AND CaO BY NITRIC ACID FROM ASH-SLAG WASTES OF THERMAL POWER PLANTS
}

\author{
${ }^{a}$ Ukrainian State University of Chemical Technology, Dnipro, Ukraine \\ b National Technical University «Kharkiv Polytechnic Institute», Kharkiv, Ukraine \\ c National Technical University of Ukraine «Igor Sikorsky Kyiv Polytechnic Institute», Kyiv, Ukraine
}

\begin{abstract}
In this work, the leaching of iron(II) oxide and calcium oxide from the wastes of thermal power plants by concentrated nitric acid was investigated. A laboratory unit for the study of leaching processes was developed. It was found that the concentrations of iron(II) oxide and calcium oxide in the solution increase with increasing the temperature of the leaching process by nitric acid. The influence of the ratio of reagents on the leaching of iron(II) oxide and calcium oxide from ash and slag wastes was established. An increase in the leaching time in the range of 15-90 minutes positively affects the process of extraction of iron(II) oxide and calcium oxide from ash and slag wastes. The calculated degree of extraction of iron(II) oxide and calcium oxide from ash and slag wastes, as the main criterion for leaching processes, showed that an increase in leaching duration leads to a more complete transition of iron(II) and calcium into solutions. Based on the analysis of the obtained experimental data, the main technological parameters for the extraction of iron(II) oxide and calcium oxide from ash and slag wastes in nitric acid solution have been determined.
\end{abstract}

Keywords: power plant, wastes, ash, slag, separation, leaching, secondary raw materials, nitrate solution.

DOI: $10.32434 / 0321-4095-2022-140-1-95-99$

\section{Introduction}

Mining, chemical, metallurgical, machinebuilding, fuel and energy, building and agriculture industries are main sources of wastes. In recent years, much attention is given to wastes of the energy sector, in particular, generated in power plants. The basis of energy sector in Ukraine today is thermal power plants on organic fuel, providing $75-80 \%$ of the total electricity production. The development of thermal power is forecast with the predominant using of coal, the share of which in 2030 will be $85.1 \%$ in the fuel balance. During the combustion of coal, a significant amount of ash and slag is formed on the thermal power plants to produce heat and electricity [1].

Ash and slag wastes are rich in metal oxides, and even their content is sometimes significantly higher than in the original ores that contain them. The mineralogical composition of ash-slag wastes is heterogeneous and depends mainly on the type of coal combustion and the type of boiler equipment. Mainly ash-slag wastes are rich in oxides of silicon, aluminum, iron and calcium [2,3].

In turn, the removal of silicon and aluminum oxides by conventional leaching methods is not rational due to the formation of a large number of aluminosilicates of various compositions. Leaching of iron and calcium oxides is more possible due to the formation of water-soluble salts in mineral acid solutions [4]. Fan et al. [5] and Shemi et al. [6] investigated the removal of aluminum by sulfuric acid in order to obtain coagulants.

Thus, at present, the study of the leaching of iron oxide using nitric acid is relevant, and the resulting solutions of nitric acid can be used in the future to obtain complex mineral fertilizers with micro- and macro-elements.

\section{Experimental}

In the present work, ash-slag wastes (ASW) of the Dnipropetrovsk region was used, which is a friable material of grayish-black color with different fractional composition. The chemical composition of the wastes is shown in Table. We used $40 \%$ aqueous 
solution of nitric acid.

Chemical composition of the initial ash-slag wastes

\begin{tabular}{c|c}
\hline Component & Content, $\%$ \\
\hline $\mathrm{CaO}$ & 2.76 \\
\hline $\mathrm{FeO}$ & 29.4 \\
\hline $\mathrm{Al}_{2} \mathrm{O}_{3}$ & 17.4 \\
\hline $\mathrm{SiO}_{2}$ & 42.6 \\
\hline $\mathrm{S}$ & 0.27 \\
\hline $\mathrm{C}$ & 3.53 \\
\hline Inert components & 4.04 \\
\hline
\end{tabular}

The scheme of experimental installation of the process of interaction of ash-waste with nitric acid is presented in Fig. 1. The mixture of ash wastes with nitric acid was placed in the reaction vessel (1). The temperature of the process was maintained using a thermostat (3) equipped with a cover (5) with a mercury thermometer (4), a two-blade mixer with a fixed number of revolutions (2), into which the reaction vessel was immersed. The gas phase, which was formed due to heating of the interaction products, was removed through the gas outlet (6), where the gas was supplied to the cascade of three glasses of Drexel. The experiment was carried out at the temperature of $298-373 \mathrm{~K}$ for $15-90$ minutes. The process of interaction of ash-slag wastes with nitric acid was carried out at the following wet ratio $\mathrm{HNO}_{3}$ :ASW: $0.5: 1 ; 1: 1 ; 1.5: 1$ and 2:1.

After the process was finished, the solution was filtered, and the resulting sediment was washed with $1 \%$ solution of nitric acid. If necessary, the sediment was again leached in a new portion of a reagent. The solution and sediment obtained during leaching were studied for the presence of valuable elements.

The study of the phase and chemical composition of ash-slag wastes and obtained liquid

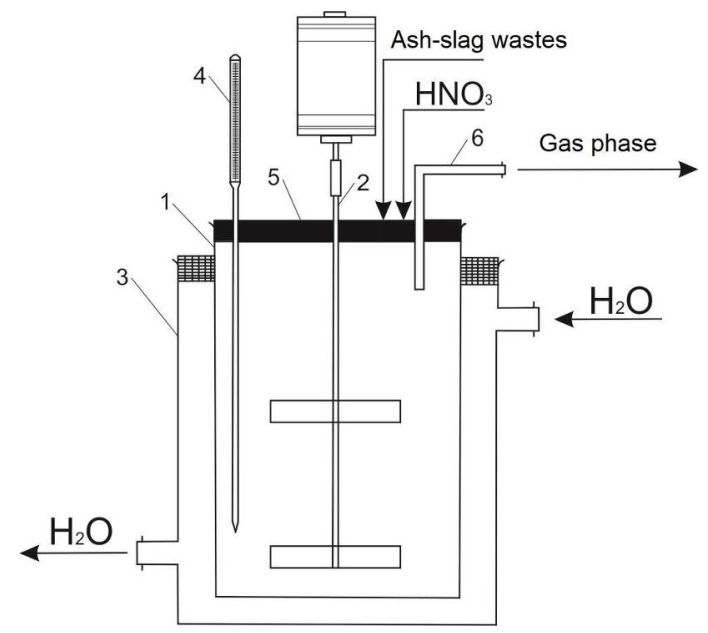

Fig. 1. Scheme of experimental installation for the interaction of ash-slag wastes with nitric acid: 1 - reaction vessel;

2 - two-blade mixer with electric drive; 3 - thermostat; 4 - thermometer; 5 - cover; 6 - gas outlet pipe

and solid samples was carried out by using the following methods of analysis [5-7]: X-ray phase analysis (diffractometer DRON-3) and X-ray fluorescence analysis (an analyzer EXPERT 3L). The detection limit of elements in $100 \mathrm{~s}$ (from $12 \mathrm{mg}$ to $92 \mathrm{U}$ ) was not less than $0.05 \%$. SDD with a nominal statistical loading of the spectroscopic path of $52000 \mathrm{1} / \mathrm{s}$ served as a detector. The resolution of the detector (for $\mathrm{KaMn}$ ) at nominal loading did not exceed $149 \mathrm{eV}$. The oxygen content was determined by the difference. To compile the results of the research, the software complex «OriginPro 8.5 SR1» was used. The determination of the extraction degree of elements from ash-slag wastes by nitrate solution was carried out according to the method disrobed elsewhere [7].

\section{Results and discussion}

Preliminary studies [8,9] showed that nitric acid

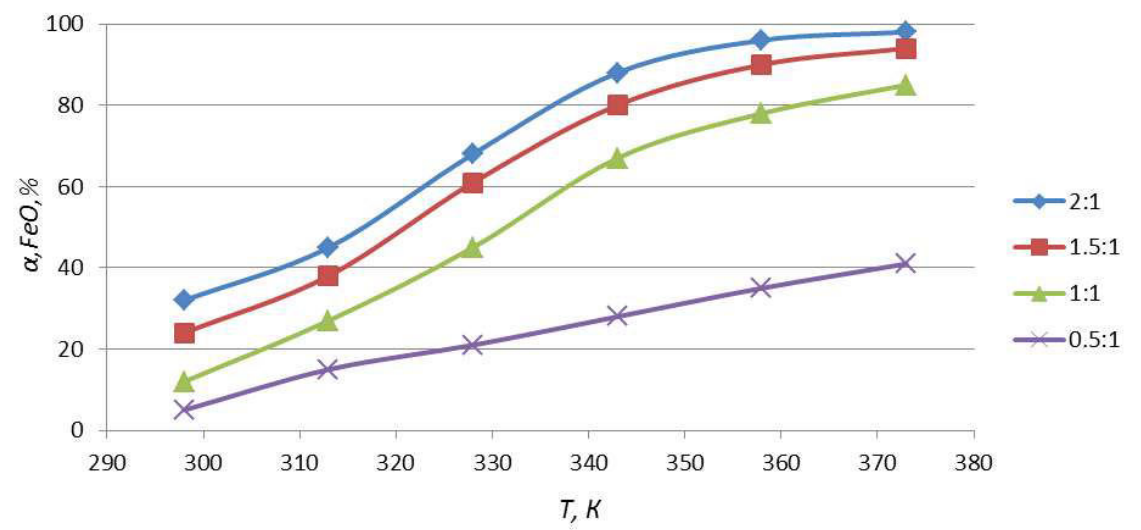

Fig. 2. Dependence of the degree of leaching of $\mathrm{FeO}$ on temperature at different ratios of reagents $\mathrm{ASW}: \mathrm{HNO}_{3}$ ( $\tau=90 \mathrm{~min}, \operatorname{Re}=600$ ) 


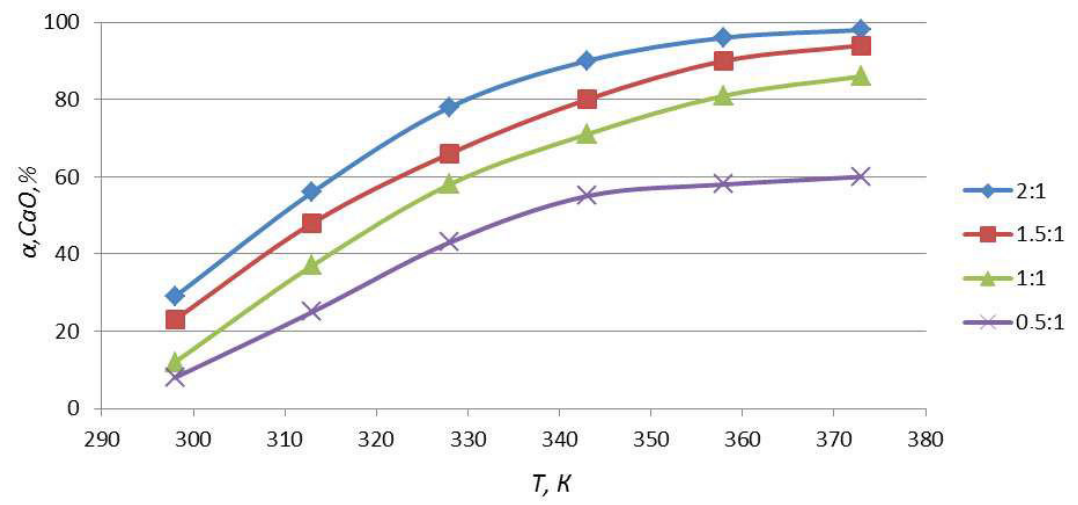

Fig. 3. Dependence of the degree of leaching of $\mathrm{CaO}$ on temperature at different ratios of reagents $\mathrm{ASW}: \mathrm{HNO}_{3}$ ( $\tau=90 \mathrm{~min}, \mathrm{Re}=600$ )

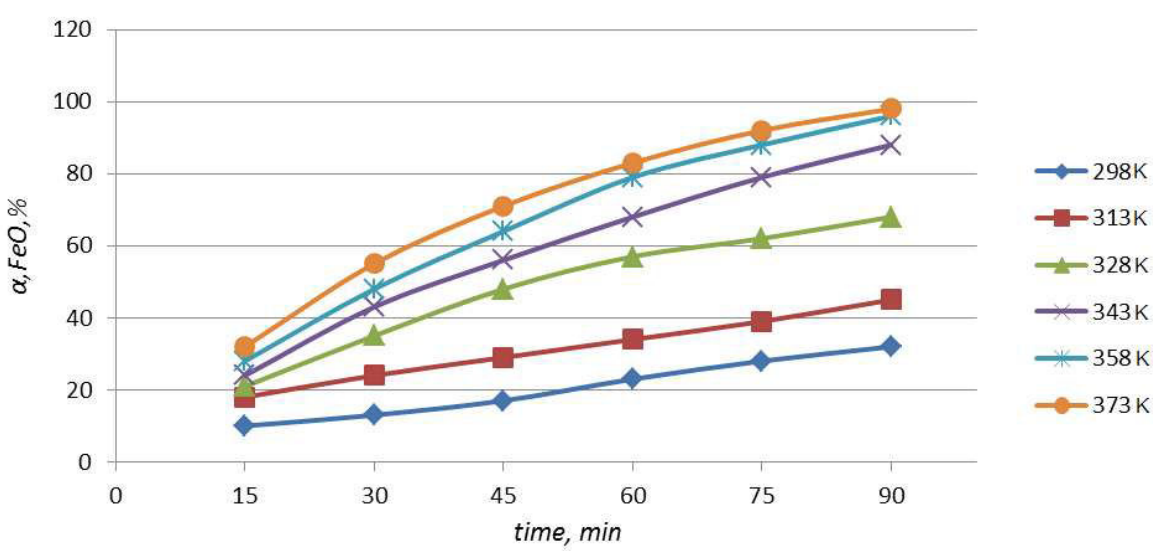

Fig. 4. Dependence of the degree of leaching of $\mathrm{FeO}$ on the time of interaction of ASW with nitric acid at different temperatures (ASW: $\mathrm{HNO}_{3}=2: 1, \mathrm{Re}=600$ )

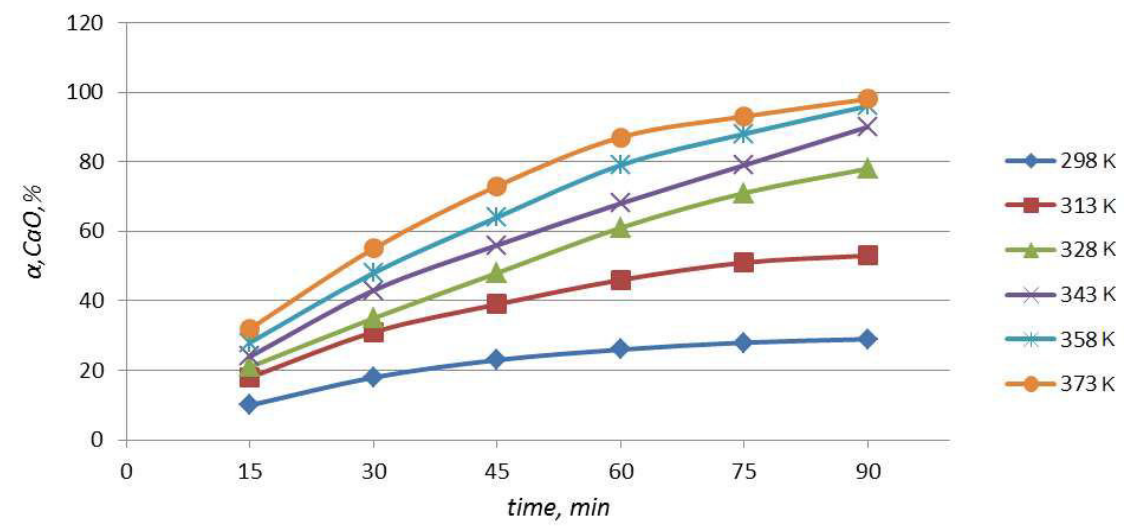

Fig. 5. Dependence of the degree of leaching of $\mathrm{CaO}$ on the time of interaction of ASW with nitric acid at different temperatures $\left(\mathrm{ASW}: \mathrm{HNO}_{3}=2: 1, \mathrm{Re}=600\right)$

is the most optimal for extracting iron from ash-slag wastes. A series of experiments were carried out to determine the effect of particle size and temperature on the leaching process of ash-slag wastes. The effects of temperature on the degree of extraction of iron oxide (II) and calcium oxide at different ratio of reagents during leaching with nitric acid are shown in Figs. 2 and 3.
The obtained experimental data indicate that the degree of transformation of $\mathrm{FeO}$ and $\mathrm{CaO}$ increases by increasing temperature. This is also associated with an increase in the $\mathrm{pH}$ of the medium from -0.8 to 3.2 , which causes increasing the viscosity of the medium, promoting better transfer of ASW elements to the solution.

The time of the reagents interaction determines 
the transformation degree of $\mathrm{FeO}$ and $\mathrm{CaO}$, the productivity of technology and the size of the neutralization reactors. The results of the experimental measurements are shown in Figs. 4 and 5.

Analysis of the experimental data shown in Figs. 4 and 5 indicates that an increase in the temperature from $298 \mathrm{~K}$ to $373 \mathrm{~K}$ leads to a significant change in the degree of extraction of iron and calcium oxides from the ASW. Therefore, the following technologically appropriate temperatures of the process were chosen: $358-373 \mathrm{~K}$. At these temperatures, the degree of extraction of $\mathrm{FeO}$ and $\mathrm{CaO}$ is $96-98 \%$. The highest degree of extraction of $\mathrm{FeO}$ and $\mathrm{CaO}$ reaches is achieved at the ratio ASW: $\mathrm{HNO}_{3}=2: 1$, thus it is chosen as technologically feasible one.

A series of experiments were carried out to determine the impact of the size of the raw material particles on the $\mathrm{FeO}$ and $\mathrm{CaO}$ extraction process (Figs. 6 and 7).

Analysis of the obtained experimental data from Figs. 6 and 7 shows that an increase in the particle size of the starting material from $0.25 \mathrm{~mm}$ to $1 \mathrm{~mm}$ leads to a significant change in the degree of

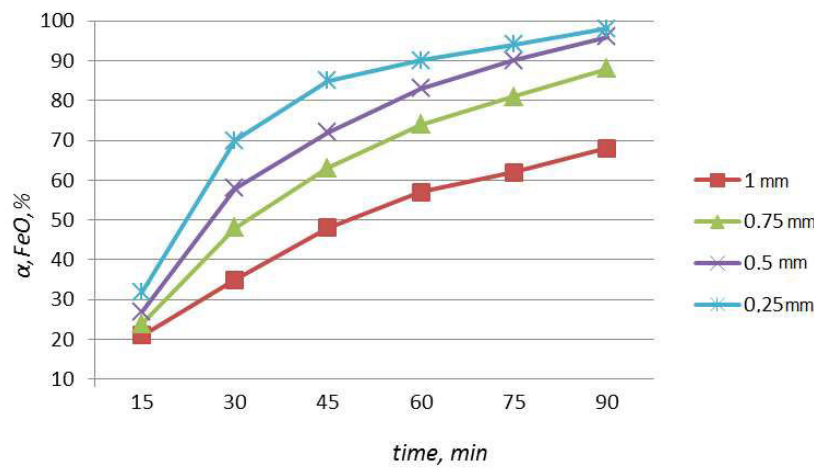

Fig. 6. Dependence of the degree of leaching of $\mathrm{FeO}$ on the interaction time at different particle size of ASW (ASW: $\mathrm{HNO}_{3}=2: 1, \mathrm{Re}=600, \mathrm{~T}=373 \mathrm{~K}$ )

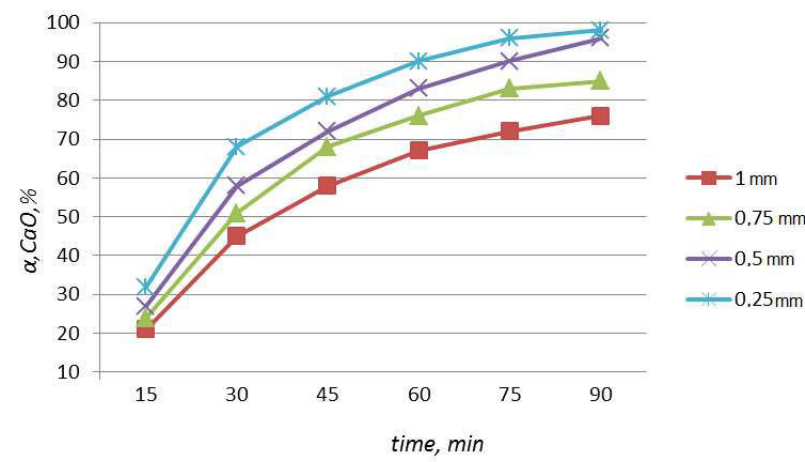

Fig. 7. Dependence of the degree of leaching of $\mathrm{CaO}$ on the interaction time at different particle size of ASW (ASW: $\mathrm{HNO}_{3}=2: 1, \mathrm{Re}=600, \mathrm{~T}=373 \mathrm{~K}$ ) extraction of the ASW. This indicates that the leaching process is additionally involves a diffusion step. Therefore, $0.25-0.5 \mathrm{~mm}$ was chosen as the technologically feasible particle size, at which the degree of conversion of $\mathrm{FeO}$ and $\mathrm{CaO}$ is $96-98 \%$. The highest degree of conversion of $\mathrm{FeO}$ and $\mathrm{CaO}$ is reached when the particle size is $0.25 \mathrm{~mm}$, so it is chosen as technologically feasible one.

\section{Conclusions}

We have studied the leaching of ash-slag wastes by nitric acid. We found out that the particle size of the initial material, the ratio of reagents, the process temperature and the mixing time have a significant effect on the extraction degree of iron(II) oxide and calcium oxide. The processes of extracting these compounds from wastes should be carried out under the following conditions: the size of the initial material of $0.25-0.5 \mathrm{~mm}$, the mixing time of $75-90$ minutes and the leaching temperature of $358-373 \mathrm{~K}$. The extraction degree of iron(II) oxide and calcium oxide reaches almost $100 \%$.

\section{REFERENCES}

1. Khlopytskyi A., Makarchenko N. Prospects of development of processing solid slag wastes from thermal power plants in to finished products // Odes'kyi Politechn. Univ. Pratsi. - 2013.Vol.3. - No. 42. - P.91-93.

2. Khlopytskyi A., Makarchenko N. Prospects for recycling of ash and slag waste from thermal power plants // Universum. Tekhn. Nauki. Elektron. Nauchn. Zhurn. - 2013. - Vol. 1. No. 1. - P.1-8.

3. Kierczak J., Chudy K. Mineralogical, chemical, and leaching characteristics of coal combustion bottom ash from a power plant located in northern Poland // Pol. J. Environ. Stud. - 2014. - Vol.23. - No. 5. - P.1627-1635.

4. Hlopitskiy A.A. Study of complex recovery of solid slag waste from thermal power plants in the target components // Chem. Mater. Eng. - 2015. - Vol.3. - No. 1. - P.1-5.

5. Production of a complex coagulant from fly ash / Fan M., Brown R.C., Wheelock T.D., Cooper A.T., Nomura M., Zhuang Y. // Chem. Eng. J. - 2005. - Vol.106. - P.269-277.

6. Extraction of aluminium from coal fly ash: identification and optimization of influential factors using statistical design of experiments / Shemi A., Ndlovu S., Sibanda V., Van Dyk L.D. // Int. J. Miner. Process. - 2014. - Vol.127. - P.10-15.

7. Vasil'ev V. Analiticheskaya khimiya. - M.: Vysshaya Shkola, 1989.

8. Vol'dman G., Zelikman A. Teoriya gidrometallurgicheskikh protsessov. - M.: Intermet Inzhiniring, 2003.

9. Plasma-chemical formation of silver nanodispersion in water solutions / Skiba M., Pivovarov A., Makarova A., Pasenko O., 
Khlopytskyi A., Vorobyova V. // East. Eur. J. Enterprise Technol. - 2017. - Vol.6. - No. 90. - P.59-65.

Received 16.10.2021

\section{ВИЛУГОВУВАННЯ FеО ТА СаО НІТРАТНОЮ КИСЛОТОЮ ІЗ ЗОЛОШЛАКОВИХ ВІДХОДІВ ТЕПЛОЕЛЕКТРОСТАНЦЙ}

\section{О. Хлопицький, А. Савенков, О. Близнюк, М. Скіба, В. Воробйова, Н. Масалітіна}

В даній роботі встановлено закономірності вилучення оксиду заліза (II) та оксиду кальцію з відходів теплових електростанцій вилуговуванням їх концентрованою азотною кислотою. Розроблена лабораторна установка для дослідження процесів вилуговування. Виявлено, що концентрація оксиду заліза(II) та оксиду кальцію у розчині зростає при збільшенні температури процесу вилуговування азотною кислотою. Досліджено вплив співвідношення реагентів на процес вилуговування оксиду заліза(II) та оксиду кальцію із золошлакових відходів. Встановлено, що збільшення часу вилуговування в інтервалі 15-90 хв позитивно впливає на процес вилучення оксиду заліза(II) та оксиду кальцію із золошлакових відходів. Ступінь вилучення оксиду заліза(II) та оксиду кальцію із золошлакових відходів, як основний критерій процесів вилуговування, показав, що збільшення часу приводить до більш повного переходу заліза(II) та кальцію у розчин. На підставі аналізу отриманих експериментальних даних визначені основні технологічні параметри вилучення оксиду заліза(II) та оксиду кальцію із золошлакових відходів у азотнокислий розчин.

Ключові слова: електростанція, відходи, зола, шлак, розділення, вилучення, вторинна сировина, нітратний розчин.

\section{LEACHING OF FeO AND CaO BY NITRIC ACID FROM ASH-SLAG WASTES OF THERMAL POWER PLANTS}

A. Khlopytskyi ${ }^{a,}$, A. Savenkov ${ }^{b}$, O. Bliznjuk ${ }^{b}$, M. Skiba ${ }^{a}$, V. Vorobiova ${ }^{c}$, N. Masalitina ${ }^{b}$

a Ukrainian State University of Chemical Technology, Dnipro, Ukraine

b National Technical University «Kharkiv Polytechnic Institute», Kharkiv, Ukraine

c National Technical University of Ukraine «Igor Sikorsky Kyiv

Polytechnic Institute», Kyiv, Ukraine

* e-mail: ahlopitskiy@gmail.com

In this work, the leaching of iron(II) oxide and calcium oxide from the wastes of thermal power plants by concentrated nitric acid was investigated. A laboratory unit for the study of leaching processes was developed. It was found that the concentrations of iron(II) oxide and calcium oxide in the solution increase with increasing the temperature of the leaching process by nitric acid. The influence of the ratio of reagents on the leaching of iron(II) oxide and calcium oxide from ash and slag wastes was established. An increase in the leaching time in the range of 1590 minutes positively affects the process of extraction of iron(II) oxide and calcium oxide from ash and slag wastes. The calculated degree of extraction of iron(II) oxide and calcium oxide from ash and slag wastes, as the main criterion for leaching processes, showed that an increase in leaching duration leads to a more complete transition of iron(II) and calcium into solutions. Based on the analysis of the obtained experimental data, the main technological parameters for the extraction of iron(II) oxide and calcium oxide from ash and slag wastes in nitric acid solution have been determined.

Keywords: power plant; wastes; ash; slag; separation; leaching; secondary raw materials; nitrate solution.

\section{REFERENCES}

1. Khlopytskyi A, Makarchenko N. Prospects of development of processing solid slag wastes from thermal power plants in to finished products. Odes 'kyi Politechnichnyi Universytet Pratsi. 2013; 3(42): 91-93.

2. Khlopytskyi A, Makarchenko N. Prospects for recycling of ash and slag waste from thermal power plants. Universum Tekhn Nauki Elektron Nauchn Zhurn. 2013; 1(1): 1-8. (in Russian).

3. Kierczak J, Chudy K. Mineralogical, chemical, and leaching characteristics of coal combustion bottom ash from a power plant located in northern Poland. Pol J Environ Stud. 2014; 23(5): 1627-1635.

4. Hlopitskiy AA. Study of complex recovery of solid slag waste from thermal power plants in the target components. Chem Mater Eng. 2015; 3(1): 1-5. doi: 10.13189/cme.2015.030101.

5. Fan M, Brown RC, Wheelock TD, Cooper AT, Nomura M, Zhuang Y. Production of a complex coagulant from fly ash. Chem Eng J. 2005; 106: 269-277. doi: 10.1016/j.cej.2004.12.044.

6. Shemi A, Ndlovu S, Sibanda V, Van Dyk LD. Extraction of aluminium from coal fly ash: identification and optimization of influential factors using statistical design of experiments. Int $J$ Miner Process. 2014; 127: 10-15.

doi: 10.1016/j.minpro.2013.12.003.

7. Vasil'ev V. Analiticheskaya khimiya [Analytic chemistry]. Moscow: Vysshaya Shkola; 1989. (in Russian).

8. Vol'dman G, Zelikman A. Teoriya gidrometallurgicheskikh protsessov [The theory of hydrometallurgical processes]. Moscow: Intermet Inzhiniring; 2003. (in Russian).

9. Skiba M, Pivovarov A, Makarova A, Pasenko O, Khlopytskyi A, Vorobyova V. Plasma-chemical formation of silver nanodispersion in water solutions. East Eur J Enterprise Technol. 2017; 6(90): 59-65. doi: 10.15587/1729-4061.2017.118914. 